\title{
PENGARUH ASUPAN PROTEIN DAN ASUPAN GARAM TERHADAP KEJADIAN HIPERTENSI PADA WANITA USIA SUBUR DENGAN OBESITAS DI WILAYAH KERJA PUSKESMAS PATUMBAK TAHUN 2017
}

\author{
Wira Maria Ginting ${ }^{1}$, Etti Sudaryati ${ }^{2}$, Sorimuda Sarumpaet ${ }^{3}$ \\ Fakultas Kesehatan Masyarakat, Universitas Sumatera Utara ${ }^{123}$ \\ Surel: wira.maria.ginting@gmail.com
}

\begin{abstract}
Hypertension might be the result of obesity, where the heart works harder to pump blood. This condition is also known as high blood pressure. Obesity and hypertension are health problems that exist in Indonesia even among women of childbearing age. One of the risk factors that can cause hypertension in obesity is diet and physical activity. The purpose of this study is to determine the effect of diet and physical activity on the incidence of obesity with hypertension in women of childbearing age. This study uses case control design. The sample in this study were 104 obese women of childbearing age (52 cases and 52 controls). Data collection methods include measuring weight, height, and blood pressure. Bariatric analysis (simple logistic regression) protein intake (0.003) and salt intake (0,000). Multivariate (multiple logistic regression) there was a significant effect between protein intake $(p=0.009,0 R=27.66,95 \%$ CI $=$ 0.762-73.65), and salt intake ( $p=0.000, O R=977,95 \%$ CI $=41.58-22965)$. It is recommended for women of childbearing age to control body weight and check blood pressure regularly as well as to attend education on diet.
\end{abstract}

Keywords: Diet, Hypertension, Women of Childbearing Age

\begin{abstract}
ABSTRAK
Hipertensi bisa disebabkan oleh tubuh orang yang gemuk, jantungnya bekerja lebih keras untuk memompa darah. Kondisi ini bisa disingkat naiknya tekanan darah. Obesitas dan hipertensi adalah masalah kesehatan yang ada di Indonesia bahkan di kalangan wanita usia produktif. Salah satu faktor risiko yang dapat menyebabkan hipertensi pada obesitas adalah diet dan aktivitas fisik. Tujuan penelitian untuk mengetahui pengaruh diet dan aktivitas fisik pada kejadian obesitas dengan hipertensi pada WUS. Penelitian ini menggunakan desain case control. Sampel dalam penelitian ini adalah 104 WUS obesitas (52 kasus dan 52 kontrol). Pengambilan data menggunakan penimbangan, tinggi badan, dan tekanan darah. Analisis bariariat (regresi logistik sederhana) asupan protein (0,003) dan asupan garam (0,000). Multivariat (regresi logistik berganda) terdapat pengaruh yang signifikan antara asupan protein $(p=$ 0,009, $O R=27,66$, CI 95\% = 0,762-73,65), dan asupan garam $(p=0,000$, OR = 977, CI 95 \% = 41,58-22965). Disarankan bagi WUS untuk mengontrol berat badan dan memeriksa tekanan darah secara teratur juga mengikuti edukasi tentang diet.
\end{abstract}

Kata kunci: Pola Makan, Hipertensi, Wanita Berusia Produktif.

\section{PENDAhUluAN}

Obesitas saat ini merupakan permasalahan yang muncul di dunia, bahkan Organisasi Kesehatan Dunia (WHO) telah mendeklarasikannya sebagai epidemik global. Prevalensinya meningkat tidak saja di negara-negara maju, tetapi juga di negara-negara berkembang, termasuk Indonesia. Hasil penelitian Lancet merilis daftar negara-negara dengan tingkat obesitas tertinggi di dunia dan Indonesia berada di peringkat 10 dari Amerika Serikat, Cina, India, Rusia, Brasil, Meksiko, Mesir, 
Jerman, Pakistan dan Indonesia. Jumlah orang di dunia yang dikategorikan kelebihan berat badan pada tahun 1980 dengan jumlah 875 juta dan meningkat menjadi 2,1 miliar pada tahun 2014 (Lancet, 2014).

Pada tahun 2014 lebih dari 1,9 milyar orang dewasa yang berumur lebih dari18 tahun kelebihan berat badan (39\%), dan dari jumlah tersebut 600 juta (13\%) mengalami obesitas (WHO, 2015). Data kejadian obesitas yang dihimpun dari Riskesdas 2013 adalah perempuan obesitas IMT >25 umur $>18$ tahun di Indonesia tahun 2007 14,8\%, tahun 2010 yaitu 20,5\%, dan tahun 2013 yaitu 32,9\%. Terjadi peningkatan disetiap tahunnya (Riskesdas, 2013).

Hipertensi adalah salah satu penyebab utama mortalitas dan morbiditas di Indonesia, sehingga tata laksana penyakit ini merupakani ntervensi yang sangat umum dilakukan di berbagai tingkat fasilitas kesehatan (PERKI, 2015). Hipertensi dapat diakibatkan karena kondisi tubuh orang yang gemuk, jantungnya bekerja lebih keras dalam memompa darah.Hal ini dapat dipahami karena biasanya pembuluh darah orang-orang yang gemuk terjepit kulit yang berlemak. Keadaan ini dapat mengakibatkan naiknya tekanan darah WHO (2010) menyatakan bahwa ada lebih dari satu milyar orang di dunia ini mengalami overweight dan tiga ratus juta diantaranya mengalami obesitas.

Kegemukan atau obesitas adalah faktor risiko yang dapat meningkatkan penyakit jantung dan dapat menyebabkan kelainan metabolisme yang dapat mempengaruh tekanan darah, kolesterol, trigliserid, dan resistensi hormon insulin (WHO, 2010). Wanita usia subur (WUS) merupakan wanita usia produktif merupakan wanita yang berusia 15-49 tahun dan wanita pada usia ini berpotensi untuk mempunyai keturunan (BKKBN, 2013). Pada wanita, kurangnya aktivitas fisik sangat mempengaruhi kesehatanya apalagi jika aktivitas fisik kurang namun asupan makanan lebih banyak masuk, maka akan menyebabkan penimbunan lemak yang akan mengakitbatkan obesitas terjadi (Nurmalina, 2011).

Puskesmas Patumbak merupakan salah satu puskesmas dibawah naungan Dinas Kesehatan kota Medan dimana penyakit hipertensi menempati urutan ke-pertama dari sepuluh penyakit. Berdasarkan latar belakang diatas, penelitian ini bertujuan untuk mencari faktor-faktor yang memengaruhi kejadian hipertensi pada WUS dengan obesitas di wilayah kerja Puskesmas Patumbak Tahun 2017.

\section{METODE PENELITIAN}

Penelitian ini merupakan penelitian studi analitik observasional dengan menggunakan desain case control study bersifat retrospective. Penelitian dilakukan di wilayah kerja Puskesmas Patumbak yang berlangsung dari bulan Mei - Agustus 2017. Populasi pada penelitian ini adalah seluruh WUS dengan obesitas yang menderita hipertensi dan tidak menderita hipertensi di wilayah kerja Puskesmas Patumbak.Sampel kasus pada penelitian ini dibagi dalam dua kelompok kasus dan kelompok kontrol dengan perbandingan 1:1 dimana sampel kasus adalah WUS dengan obesitas yang menderita hipertensi dan sampel kontrol adalah WUS dengan obesitas tidak menderita hipertensi. Tekhnik sampling dalam penelitian ini adalah Consecutive sampling yaitu pemilihan sampel dengan menetapkan subjek yang memenuhi kriteria penelitian dimasukkan dalam penelitian 
sampai kurun waktu tertentu, sehingga jumlah responden dapat terpenuhi. Besar sampel dalam penelitian ini adalah 104 orang.

Variabel terikat dalam penelitian ini adalah kejadian hipertensi WUS dengan obesitas di wilayah kerja Puskesmas Patumbak.. Analisis univariat data yang digunakan adalah analisis distribusi frekuensi dan analisis bivariat data dilakukan dengan uji regresi logistik sederhana pada SPSS 16.00, analisis multivariat yang digunakan adalah Regresi logistik berganda pada tingkat kepercayaan $95 \%$, dengan metode yang digunakan dalam analisis ini adalah metode enter.

\section{HASIL DAN PEMBAHASAN}

\section{Analisis Univariat}

Adapaun hasil analisis uji univariata pengaruh asupan protein dan asupan garam terhadap kejadian hipertensi pada WUS dengan obesitas di wilayah kerja Puskesmas patumbak tahun 2017 dapat di lihata pada table 1 sebagai berikut:

\section{Tabel 1.}

Distribusi Frekuensi Responden Berdasarkan Variabel Independen pada WUS di Wilayah Kerja Puskesmas Patumbak Tahun 2017

\begin{tabular}{lcccc}
\hline \multicolumn{1}{c}{ Variabel independen } & \multicolumn{2}{c}{ Kasus } & \multicolumn{2}{c}{ Kontrol } \\
& $\mathbf{n}$ & $(\boldsymbol{\%})$ & $(\mathbf{n})$ & $(\boldsymbol{\%})$ \\
Asupan protein & 44 & 84,6 & 30 & 57,7 \\
Lebih & 8 & 15,4 & 22 & 42,3 \\
Baik & & & & \\
Asupan garam & 50 & 96,2 & 9 & 17,3 \\
Tinggi & 2 & 3,8 & 43 & 82,7 \\
Normal & & & & \\
Total & $\mathbf{5 2}$ & $\mathbf{1 0 0}$ & $\mathbf{5 2}$ & $\mathbf{1 0 0}$ \\
\hline
\end{tabular}

Hasil analisis univariat menunjukkan bahwa distribusi frekuensi responden berdasarkan asupan proteinnya lebih pada kelompok kasus terdapat 44 responden $(84,6 \%)$ yang beresiko mengalami hipertensi. Berdasarkan yang asupan garamnya tinggi pada kelompok kasus terdapat 52 responden $(96,2 \%)$ yang beresiko mengalami hipertensi.

\section{Analisis bivariat}

Hasil analisis uji bivariat menggunakan regresi logistic sederhana antara pengaruh asupan protein dan asupan garam terhadap kejadian hipertensi pada WUS dengan obesitas pada wilayah kerja Puskesmas Patumbak tahun 2017, dapat di lihat pada table 2 sebagai berikut:

Tabel 2.

Pengaruh Variabel Independen terhadap Kejadian Hipertensi pada WUS di Wilayah Kerja Puskesmas Patumbak Tahun 2017

\begin{tabular}{ccc}
\hline Variabel & $p$-value & OR \\
& & $(95 \% \mathrm{CI})$
\end{tabular}

Asupan protein 


\begin{tabular}{lcc}
\hline $\begin{array}{l}\text { Lebih } \\
\text { Baik }\end{array}$ & 0,003 & 4,033 \\
\hline $\begin{array}{l}\text { Asupan garam } \\
\text { Tinggi }\end{array}$ & & $(1,587-10,251)$ \\
Normal & 0,000 & 119,444 \\
\hline
\end{tabular}

Hasil analisis bivariat menunjukkan bahwa variabel pola makan dilihat dari asupan protein menunjukkan ada pengaruh asupan energi terhadap kejadian hipertensi pada WUS.Nilai OR = 4,033, 95\% CI (1,587- 10,251). Variabel pola makan dari asupan garam menunjukkan ada pengaruh yang antara asupan garam terhadap kejadian hipertensi pada WUS yang.Dari hasil analisis diperoleh nilai $\mathrm{OR}=119,444,95 \% \mathrm{CI}(24,468-583,080)$, artinya asupan garam yang tinggi mempunyai perkiraan peluang 119,44 kali memengaruhi hipertensi dibandingkan dengan asupan garam yang normal.

\section{Analisis multivariat}

Analisis multivariat dengan menggunakan uji regresi logistic berganda setelah dilakukan seleksi dari uji bivariat makan dilakukan uji multivariate sebagai berikut:

Tabel 3.

Hasil Analisis Uji Regresi Logistik Berganda

\begin{tabular}{ccccc}
\hline Variabel & B & Sig. & OR & $\mathbf{9 5 \%}$ C.I \\
\hline Asupan & 3,153 & 0,009 & 27,665 & $0,762-73,65$ \\
Protein & & & & \\
Asupan & $\mathbf{6 , 3 3 5}$ & $\mathbf{0 , 0 0 0}$ & $\mathbf{9 7 7 , 2 5 5}$ & $\mathbf{4 1 , 5 8 4 - 2 2 9 6 5 , 9 6}$ \\
Garam & & & & \\
Constant & $-16,49$ & 0,000 & 0,000 & \\
\hline
\end{tabular}

Hasil analisis multivariat menunjukkan bahwa variabel yang paling dominan memengaruhi kejadian hipertensi pada WUS dengan obesitas adalah pola makan yang asupan garamnya tinggi dimana memiliki nilai OR sebesar 977 yang berarti WUS dengan obesitas 977 kali perkiraan peluangnya kemungkinan menderita hipertensi dengan yang tidak mengonsumsi asupan garam normal. Population Attributable Risk (PAR) sebesar $99 \%$ yang artinya kejadian hipertensi pada WUS dengan obesitas dapat dicegah dengan memperbaiki pola makan yang asupan garamnya tinggi.

\section{a. Asupan protein}

Hasil uji bivariat dan multivariat menunjukkan ada pengaruh signifikan antara asupan protein dengan hipertensi pada WUS yang mengalami obesitas $p<0,05$. Hal ini sesuai dengan penelitian yang dilakukan oleh Katulistiwa (2013) yang menunjukkan adanya hubungan antara konsumsi protein hewani (daging) dengan kolesterol dan aterosklerosis yang dapat menyebabkan terjadinya hipertensi. Hal tersebut disebabkan, kebiasaan mengonsumsi protein hewani melebihi asupan yang dianjurkan. Konsumsi sumber protein hewani dalam jumlah yang berlebihan dapat meningkatkan 
risiko tekanan darah, dikarenakan kandungan lemak jenuh dan kolesterolnya lebih tinggi daripada sumber protein nabati (Kurniawan, 2002).

Sumber protein yang sering dikonsumsi oleh WUS pada penelitian ini adalah telur, ikan teri, ikan dencis, daging ayam dan daging babi. Protein hewani merupakan salah satu faktor risiko terjadinya hipertensi.Konsumsi protein dalam makanan sehari-hari yang dianjurkan yaitu $1 / 3$ bagian protein yang dibutuhkan berasal dari protein hewani (Almatsier, 2009). Sebuah studi pada orang dewasa di Oueen Elizabeth Collge University of London mengemukakan bahwa kelompok yang mengkonsumsi rendah protein mengalami peningkatan berat badan $1,1 \mathrm{~kg}$, sedangkan kelompok yang mengkonsumsi tinggi protein berat badanya meningkat sebesar 3,7 kg (Indira, 2012).

\section{b. Asupan garam}

Berdasarkan hasil uji bivariat dan multivariat menunjukkan ada pengaruh yang signifikan $(\mathrm{p}<0,05)$ antara konsumsi garam dengan kejadian hipertensi pada WUS yang obesitas. Kandungan garam yang berlebihan secara terus menerus mengakibatkan volume di dalam peredaran darah menjadi lebih tinggi dari yang seharusnya, akibatnya kelebihan cairan tersebut meningkatkan tekanan pada dinding pembuluh darah.

Berdasarkan hasil wawancara secara langsung dengan bertanya pengunaan garam yang digunakan adalah rata-rata wanita usia subur menggunakan garam dapur sebagai rasa masakan. Hal ini dikarenakan garam dapur sebagai pelezat makanan dan selalu digunakan untuk memasak. Garam dapur merupakan makanan yang beresiko dapat menaikkan tekanan darah. Berdasarkan penelitian Fendy Sustanto dari Nutrifood Reserarch Centre, Profram Development and Scientific Jakarta Support tahun 2011.Garam sangat erat dengan hipertensi. Setengah sendok teh garam saja bisa menaikkan tekanan darah sistolik naik sebesar 5 poin dan tekanan darah diastolik naik 3 poin.

Penelitian ini sejalan dengan Widyaningrum (2012) adanya pengaruh antara asupan natrium dengan tekanan darah. Natrium berhubungan dengan kejadian tekanan darah tinggi karena konsumsi garam dalam jumlah yang tinggi dapat mengecilkan diameter dari arteri, sehingga jantung harus memompa lebih keras untuk mendorong volume darah yang meningkat melalui ruang yang semakin sempit dan akan menyebabkan tekanan darah meningkat

\section{KESIMPULAN DAN SARAN}

\section{Kesimpulan}

Berdasarkan hasil penelitian dan pembahsan, maka dapat dikemukkan kesimpulan, sebagai berikut: Variabel yang paling dominan memengaruhi kejadian hipertensi pada WUS obesitas adalah asupan garam.

\section{Saran}

1. Bagi Puskesmas Patumbak

Puskesmas sebagai pelayanan masyarakat pertama berperan aktif dalam mengkordinasi setiap bidan desa dan gizi melibatkan kader-kader posyandu juga posbindu serta memberikan penyuluhan atau pembagian informasi melalui media-media tertentu seperti leaflet dan spanduk.

2. Bagi masyarakat Patumbak

a. Rutin memeriksakan kesehatan ke Posbindu PTM atau Puskesmas setempat. 
b. Berperan aktif dalam menambah pendidikan/pengetahuan tentang kesehatan yang diberikan oleh tim penyuluhan kesehatan, bidan desa dan petugas puskesmas.

c. Menghindari dan mengontrol makanan asin, penggunan garam dalam setiap pengolahan juga bumbu penyedap rasa dalam kehidupan sehari-hari.

\section{REFERENSI}

Arieska DKK. 2015. Pedoman Tatalaksana Hipertensi Pada Penyakit Kardiovaskular. PERKI : JakartaSusanto, F. (2016, Maret Jumat). Pengelolaan Program CSR Generator (Gerakan Sehat Seru di Kantor) PT. Nutrifood Indonesia. (D. A. Miftah, Interviewer)

Mahmudah, S, dkk., 2015. Hubungan Gaya Hidup Dan Pola Makan Dengan Kejadian Hipertensi Pada Lansia Di Kelurahan Sawangan Baru Kota Depok Tahun 2015. Jurnal, Fakultas Ilmu Kesehatan, Universitas Pembangunan Nasional, Jakarta.

Nurmalina, Rina. 2011. Pencegahan \& Manajemen Obesitas. Bandung :Elex Media Komputindo.

Widyaningrum, H. 2011. Kitab tanaman Obat Nusantara. Yogyakarta : Media Pressindo.

Suryaputra K, Nadhiroh SR. Perbedaan pola makan dan aktivitas fisik antara remaja obesitas dengan non obesitas. Makara Kesehatan. 2012; 16(1): 45-50

Wang YF, Yancy Jr WS, Yu D, Champagne C, Appel LJ, Lin P-H. The relationship between dietary protein intake and blood pressure: results from the PREMIER study. J Hum Hypertens. 2008; $22: 745-54$.

BKKBN, 2011. Batasan dan Pengertian Pemutakhiran Data Keluarga (MDK), diakses 25 April 2017; http://aplikasi.bkkbn.go.id/mdk/BatasanMDK.aspx

Botelho NM, Silva IF, Tavares JR, Lima LO, 2014. Causes of Maternal Death in Pará State Brazil, diakses 25 April 2017; https://www.ncbi.nlm.nih.gov/pubmed/25076073

Balitbang Kemenkes RI. 2013. Riset Kesehatan Dasar; RISKESDAS. Jakarta: Balitbang Kemenkes RI

Suiraoka Ip., 2016. Penyakit Degeneratif, Yogyakarta: Penerbit Nuha Medika

World Health Organization (WHO), 2013. A Global Brief on Hypertension, http://ish-world.com/downloads/pdf/global_brief_hypertension.pdf 